\title{
VERBA BEROBJEK GANDA BAHASA JEPANG
}

\author{
Made Ratna Dian Aryani \\ Fakultas Ilmu Budaya Universitas Udayana \\ dian_aryani@unud.ac.id
}

\begin{abstract}
Abstrak
Penelitian ini bertujuan mendeskripsikan kata kerja yang melibatkan objek ganda, yaitu kata kerja ageru 'memberi', oshieru 'mengajar/ajar', kureru 'memberi',dan kau 'membeli', sehingga memunculkan objek tak langsung dalam struktur kalimat bahasa Jepang (BJ). Teori yang dipergunakan dalam penelitian ini adalah Givon (2001), Kindaichi (1976), Tsunoda (2002), Tsujimura (1996), dan Nitta (1991). Penelitian ini menunjukkan bahasa Jepang merupakan bahasa yang bertanda atau berkasus. Kasus dalam bahasa Jepang berkaitan erat dengan sistem kebermarkahan dalam struktur kalimat bahasa Jepang. Pemarkah tersebut dilekatkan setelah nomina (kata benda). Pemarkah atau partikel yang menyatakan objek langsung adalah pemarkah akusatif $o$ dan pemarkah datif $n i$ sebagai pemarkah objek tak langsung. Hasil penelitian ini adalah (1) verba-verba yang memungkinkan munculnya objek ganda, khususnya objek tak langsung (OTL) dalam konstruksi bahasa Jepang merupakan verba transitif atau verba aksi berpemarkah ni, yaitu verba ageru 'memberi', oshieru 'mengajar/ajar', kureru 'memberi', dan kau 'membeli', dan (2) verba-verba tersebut secara semantis merupakan keizoku doushi 'verba kontinuatif'.
\end{abstract}

Kata kunci : objek langsung, objek tak langsung, objek ganda

\section{PENDAHULUAN}

Keruntunan atau linearitas merupakan aspek dan sekaligus ciri suatu bahasa. Keruntunan yang dimaksud tersebut ada dua hal, yaitu (1) adanya satuan-satuan lingual sebagai unsur bahasa yang diartikulasikan, (2) adanya urutan satuan-satuan itu sebagai alat tatabahasa yang membentuk konstruksi (Sudaryanto, 1983: 1). Satuan tersebut diurutkan dalam proses peruntunan dan membentuk susunan beruntun. Secara tipologis, bahasa-bahasa di dunia menunjukkan bahwa pola urutan dalam setiap bahasa memiliki corak internal bawahannya sendiri yang menyangkut konstruksi yang ada di dalamnya.

Lehmann (dalam Sudaryanto, 1983: 6) menyatakan bahwa "setiap sentral dari suatu bahasa adalah verba". Artinya, verbalah yang pertama-tama menentukan adanya berbagai struktur dari konstruksi dalam bahasa yang bersangkutan beserta perubahannya. Fungsi utama verba adalah sebagai predikat atau sebagai inti predikat dalam kalimat. Givon (2001:64-73) mencermati bahwa karakteristik sebuah verba dapat diamati melalui tiga ciri, yaitu semantis, morfologis, dan sintaktis. Ciri semantis verba cenderung mengacu pada keadaan, peristiwa dan tindakan. Ciri morfologis menujukkan bahwa verba ditandai oleh penambahan afiks yang dalam bahasa tertentu menyatakan modalitas, aspek, kala, sangkalan, persesuaian pronominal, dan penanda kasus. Sementara itu, ciri sintaktis mengungkapkan bahwa verba secara umum merupakan predikat kalimat yang dalam penelitian ini akan tetap disebut verba kalimat.

Salah satu karakteristik bahasa Jepang adalah sistem kebermarkahan. Tsujimura $(1996 ; 165)$ menyatakan bahwa dalam setiap konstituen bahasa Jepang (BJ), terdapat pemarkah untuk menjelaskan fungsinya, yaitu pemarkah nominative subjek (topik) yaitu ga dan topik adalah wa, pemarkah akusatif objek adalah o/wo, pemarkah datif adalah ni, pemarkah genitif kepemilikan adalah no, pemarkah pelengkap adalah to. Pemarkah yang sering disebut partikel (kata bantu) merupakan salah satu jenis kata yang memiliki sifat tidak bisa berdiri sendiri, tidak mengalami perubahan bentuk, kehadirannya berposisi setelah jenis kata lain, dan berfungsi menghubungkan kata dengan kata, frasa dengan frasa, kalimat dengan kalimat. Bila suatu kata yang hanya terdiri atas partikel, akan tidak mempunyai arti apa-apa. Kaidah bahasa Jepang (BJ) menyatakan bahwa partikel sesungguhnya tidak mempunyai arti, kecuali arti yang berhubungan dengan konteksnya.

Dalam kaitannya dengan verba di dalam kalimat, menurut Verhaar (1999) verba dalam suatu konstruksi kalimat merupakan konstituen 
induk. Verba sebagai konstituen induk mempunyai tugas melahirkan konstituenkonstituen yang lain. Konstituen tersebut dalam kalimat disebut dengan nomina. Sifat-sifat (peran) nomina juga bergantung pada sifat yang dimiliki oleh verba sebagai induk. Sebagai contoh:

$\begin{array}{clc}\text { 田中先生は } & \text { 私たちに } & \text { 日本語を } \\ \text { Tanaka } & \text { watashitachi } & \text { nihongo o } \\ \text { sensei wa } & \boldsymbol{n i} & \\ \text { guru } & \text { kami-Dat } & \text { bahasa } \\ \begin{array}{c}\text { Tanaka-Top } \\ \text { Subjek }\end{array} & \text { OTL } & \text { Jepang-Ak } \\ \begin{array}{c}\text { Objek } \\ \text { Onak }\end{array} & \end{array}$

教えて下さいます。 oshite kudasaimasu.

pengajaran-memberi- sedang (polite). Verba

'Guru Tanaka sedang mengajarkan (memberi pengajaran) bahasa Jepang untuk kami. / Guru Tanaka sedang mengajarkan kami bahasa Jepang.'

\section{（2）彼女は バケツに 水を Kanojo wa baketsu ni mizuo dia (perempuan) ember-Lok air-Ak -Top

Subjek Keterangan Objek

\author{
入れます。 \\ iremasu. \\ memasukkan-akan (polite) \\ Verba \\ 'Dia akan memasukkan air ke ember.' \\ (JL, 1996: 135)
}

Pada contoh kalimat (1), Tanaka sensei wa 'guru Tanaka' adalah pelaku (agen), watashitachi $n i$ 'kami' adalah benefaktif/ pasien (datif/ OTL), nihongo o 'bahasa Jepang' adalah tema (objek), dan verba oshite kudasaimasu 'mengajarkan/ memberi pengajaran' pun merupakan verba aksi yang menuntut kehadiran argumen datif. Verba oshiete kudasaru 'memberi pengajaran' pun memerlukan argumen pemberi, argumen penerima, dan argumen sesuatu barang/jasa. Pada contoh struktur kalimat (1) menunjukkan kesantunan berbahasa. Verba kudasaru 'memberi' merupakan penggunaan kesantunan secara pilihan kata yang menyatakan Tanaka sensei sebagai guru yang berstatus lebih tinggi kepada watashitachi 'kami' sebagai murid yang berstatus lebih rendah. Berdasarkan fungsi sintaksis, konstruksi contoh kalimat (1) argumen berpemarkah $\boldsymbol{n i}$ tersebut merupakan objek tak langsung atau datif.

Pada contoh kalimat (2), kanojo wa 'dia (perempuan) adalah pelaku (agen), baketsu $n i$ 'ember' adalah arah (lokatif), mizu o 'air' adalah tema (objek), dan verba iremasu 'akan memasukkan' pun merupakan verba aksi yang menuntut kehadiran argumen objek. Namun, contoh kalimat (2), pemarkah ni yang muncul, bukanlah sebagai pemarkah datif, tetapi pemarkah yang bermakna lokatif, yaitu menunjukkan ke arah. Verba ireru 'memasukkan' memerlukan argumen pelaku, argumen yang menyatakan tujuan/ arah, dan argumen yang menyatakan sesuatu barang. Secara fungsi, penggunaan pemarkah $\boldsymbol{n i}$ pada konstruksi contoh kalimat (2) tersebut menyatakan sebagai fungsi keterangan, yaitu keterangan tempat.

Permasalahan seperti dicontohkan di atas, penting untuk dikaji lebih lanjut agar dapat dijabarkan penggunaan partikel sebagai objek dan perbedaan objek langsung dengan objek taklamngsung dalam struktur kalimat BJ.

\section{Metode Penelitian}

Penelitian verba berobjek ganda bahasa Jepang (BJ) ini merupakan bentuk penelitian deskriptif yang bersifat kualitatif, eksplanatoris, dan sinkronis karena pendeskripsian data dalam penelitian ini dilakukan dengan cara memberikan gambaran dan penjelasan keadaan atau realitas bahasa seperti apa adanya. Metode yang digunakan dalam penelitian ini adalah metode padan dan metode agih. Metode padan adalah metode yang alat penentunya di luar, terlepas, dan tidak menjadi bagian dalam bahasa yang bersangkutan (Sudaryanto, 2015: 13-15). Metode padan yang digunakan dalam penelitian ini adalah metode padan referent (penentunya adalah kenyataan yang ditunjuk oleh bahasa), dan metode padan translasional (menggunakan bahasa lain) yang alat penentunya adalah langue lain dalam hal ini adalah bahasa Indonesia. Metode padan referensial dengan alat penentu referen diterapkan untuk menentukan ciri-ciri semantis verba bahasa Jepang. Misalnya, (1) naguru 'memukul' ialah kata yang menyatakan tindakan; (2) kawaku 'mengering' ialah kata yang menyatakan makna proses; (3) kowareru 'rusak, pecah' ialah kata yang menyatakan makna keadaan. Ketiga kata 
tersebut merupakan jenis verba, tetapi makna dari ketiga verba tersebut memiliki referen yang berbeda.

Penggunaan metode agih tersebut, disebabkan masalah yang dikaji berkaitan dengan alat penentunya bagian dari bahasa yang bersangkutan itu sendiri (Sudaryanto, 2015:18-19). Teknik lanjutan yang dipergunakan dalam penganalisisan data adalah sebagai berikut:

\section{Teknik Ganti}

Teknik penyulihan digunakan untuk mengetahui kadar kesamaan kelas atau kategori unsur terganti dengan unsur pengganti dalam verba berobjek ganda bahasa Jepang (BJ).

$\begin{array}{ll}\text { (1) a. Jiroが } & \text { Hanakoに } \\ \text { Jiro ga } & \text { Hanako ni } \\ \text { Jiro-Nom } & \text { Hanako-Dat } \\ \text { 花を } & \text { あげます。 } \\ \text { hana o } & \text { agemasu } \\ \text { bunga-Ak } & \text { memberi (akan) }\end{array}$

'Jiro akan memberikan bunga kepada Hanako.'

$\begin{array}{cl}\text { b.* Jiroが } & \text { 東京に } \\ \text { Jiro ga } & \text { Tokyo } n i \\ \text { Jiro-Nom } & \text { Tokyo-Lok } \\ \text { 花を } & \text { あげます。 } \\ \text { hana o } & \text { agemasu. } \\ \text { bunga-Ak } & \text { memberi (akan) }\end{array}$

'Jiro akan memberikan bunga di Tokyo.'

$$
\begin{array}{ll}
\text { c.* Jiroが } & \text { Hanakoを } \\
\text { Jiro ga } & \text { Hanako o } \\
\text { Jiro-Nom } & \text { Hanako-Ak } \\
\text { 花を } & \text { あげます。 } \\
\text { hana o } & \text { agemasu. } \\
\text { bunga-Ak } & \text { memberi (akan) }
\end{array}
$$

* 'Jiro akan memberi bunga Hanako.'

Analisis contoh kalimat (1) menunjukkan konstituen bermarkah datif pada (1b) yang telah disulihkan dengan nomina tempat, maka secara gramatikal bahasa Jepang (BJ) konstruksi tersebut berterima, namun secara makna bahasa Jepang menjadi tidak berterima. Karena penggunaan pemarkah ni pada konstruksi (1b) tersebut tidak sesuai secara makna. Selanjutnya, contoh kalimat (1c) pun tidak berterima secara gramatikal maupun makna. Hal itu disebabkan penggunaan objek akusatif (pemarkah o) tidak diperbolehkan secara gramatikal bahasa Jepang (BJ).

\section{PEMBAHASAN}

Struktur frasa bahasa Jepang, pada umumnya lekat kiri dari intinya. Hal ini merupakan perbedaan yang mendasar antara bahasa Jepang dengan bahasa Inggris atau bahasa Indonesia. Meskipun demikian, kekhasan ini bukan berarti tidak terdapat pada bahasa-bahasa yang lainnya karena struktur yang sama dapat diamati pada bahasa Korea, bahasa Cina, bahasa Turki, dll. Pewatas struktur dasar frasa bahasa Jepang adalah pemarkah, yang sering disebut dengan partikel atau kata bantu. Dengan kata lain, sebuah kelompok kata dikatakan frasa apabila ditandai dengan kata bantu. Partikel ini sangat bervariatif bergantung pada fungsinya antara lain apabila memarkahi subjek ditandai dengan pemarkah $g a$, objek ditandai dengan pemarkah $o$, sebagai datif bisa ditandai pemarkah $n i$ atau kara, dan sebagainya. Dengan demikian, pemarkahpemarkah itu menjadi patokan atau kaidah utama dalam penentuan frasa, terlebih-lebih ketika dilakukan permutasi pada tataran frasa tersebut.

Ancangan pemahaman kalimat bahasa Jepang berdasarkan partikel kasus, untuk menganalisis data-data kalimat yang diperoleh, akan digunakan syarat-syarat seperti yang diungkapkan Tsunoda (2002: 66) berikut ini:

Syarat 1 : Peran-peran umumnya hanya terikat dengan partikel kasus : $\boldsymbol{g a}, \boldsymbol{n i}$ dan $\boldsymbol{o}$

Syarat 2 : Dalam setiap kalimat, umumnya salah satu argumen dilekati partikel kasus $\boldsymbol{g} \boldsymbol{a}$ tidak lebih dari satu.

Syarat 3 : Dalam setiap kalimat, adakalanya argumennya tidak dilekati oleh partikel kasus o, dan bila partikel kasus itu pun muncul, tidak lebih dari satu.

Syarat 4 : Dalam setiap kalimat, bila pada argumennya tidak dilekati oleh partikel $\boldsymbol{g} \boldsymbol{a}$ dan $\boldsymbol{o}$, akan muncul partikel ni.

Namun, dari kombinasi partikel kasus ini tidak berarti setiap verba berterima karena makna verba menentukan pula hubungan makna yang terjalin antara verba dengan argumen yang dimilikinya. 
Kasus dalam bahasa Jepang biasanya diberikan kepada kata benda yang merupakan salah satu fitur gramatikal yang menentukan bentuk kata benda, dalam indikator sistematis menunjukkan hubungan semantik-sintaksis dengan kalimat yang mengandung benda. Dapat dikatakan, kasus adalah fitur yang khas, dengan mengubah bentuk kata benda, hubungan sintaksis seperti subjek, objek, hubungan semantik, seperti tempat, dan objek yang akan dikenai tindakan adalah kalimat yang berisi benda yang ditunjukkan dengan tanda. Pusat dalam struktur kalimat adalah predikat. Slot predikat ini diisi verba. Tsunoda (2002) telah menyatakan kalimat verbal dwitransitif memerlukan kehadiran fungsi subjek, fungsi objek, fungsi pelengkap, dan fungsi predikat yang membentuk struktur S-O-Pel-P.

Givon (2001: 112) menyatakan bahwa verba merupakan inti proposisi yang memunculkan nomina atau frasa nominal yang wajib hadir bersama verba. Verba pun menentukan peran semantis nomina/frasa nominal dan fitur-fitur semantis nomina yang wajib hadir menemani verba dalam membangun proposisi. Selanjutnya, Givon menjelaskan bahwa struktur semantis didasarkan atas serangkaian hubungan antara verba sebagai inti dan nomina yang diikatnya memiliki hubungan semantis khusus dengan verba yang mengikatnya.

Konsepsi valensi berhubungan erat sekali dengan ketransitifan verba pada tataran morfosintaksis. Katamba (1993: 147-150) mengemukakan bahwa valensi merupakan banyaknya argumen yang diikat atau yang dibutuhkan oleh verba. Velensi merupakan jumlah argumen dalam kerangka sintaksis yang dikaitkan dengan verba yang disebabkan oleh fungsi-fungsi gramatikal. Valensi sintaksis adalah potensi verba untuk mendapatkan sejumlah argumen yang disiratkan secara morfosintaksis yang dibutuhkan verba tersebut, sedangkan valensi semantis adalah jumlah argumen semantis yang dapat diambil oleh verba tertentu.

Struktur dasar kalimat bahasa Jepang yang berpola SOV ini memiliki struktur yang berlapis yang tersusun atas frasa nomina (yang terbentuk dari gabungan nomina dan partikel), kata sifat, serta variasi verba yang semuanya berpusat pada frasa verba ( Nitta: 1991). Pola dasar yang umum, yakni berpola, $\mathrm{S}_{\text {(wa) }} \mathrm{O}_{\text {(o) }} \mathrm{V} ; \mathrm{S}_{\text {(ga) }} \mathrm{V} ; \mathbf{S}_{\text {(wa) }} \mathbf{O}_{\text {(ni) }} \mathbf{O}$ (o) $\mathbf{V} ; \mathrm{S}_{\text {(ga) }} \mathrm{O}_{\text {(o) }} \mathrm{V}$. Selain mengenal bentuk verba transitif-intransitif yang mengandung makna inheren, bahasa Jepang (BJ) pun mengenal adanya pola kalimat yang ditandai secara morfologis yang berupa morfem dasar-afiks. Seperti berikut:

a. Kalimat dasar berpola: $\mathrm{S}_{(g a)} \mathrm{V}_{\text {(intransitif) }}$

$\begin{array}{ll}\text { - 犬が } & \text { 走る。 } \\ \text { Inu ga } & \text { hashiru } \\ \text { anjing-Nom } & \text { lari } \rightarrow \text { intransitif }\end{array}$

'Anjing berlari'

b. Kalimat kausatif berpola : $\mathrm{S}_{(w a)} \mathrm{O}_{(o)} \mathrm{V}$ (intransitif menjadi verba kausatif)

$\begin{array}{lrl}\text { - 私は } & \text { 犬を } & \text { 走らせました。 } \\ \text { Watashiwa inuo } & \text { hashirasemashita. } \\ \text { saya-Top anjing-Ak } & \text { berlari(menyuruh) } \\ & & \text { telah }\end{array}$

'Saya telah menyuruh anjing berlari.'

Verba intransitif hashiru 'berlari' berubah menjadi verba kausatif hashiraseru 'menyuruh berlari'.

c. Kalimat dasar berpola: $\mathrm{S}_{(g a)} \mathrm{O}_{(o)} \mathrm{V}$ (transitif) 一 子供が牛乳を飲む。

Kodomo ga gyиипуии о поти. anak-Nom susu-Ak minum $\rightarrow$ transitif

'Anak minum susu.'

d. Kalimat kausatif berpola: $\mathrm{S}_{(g a)} \mathrm{O}_{(n i)} \mathrm{O}_{(o)} \mathrm{V}$ (transitif menjadi kausatif)

\begin{tabular}{ll} 
- 私が & 子供に \\
Watashiga & kodomo ni \\
saya-Nom & anak-Dat \\
牛乳を & 飲ませた。 \\
gyuunyuu o & nomaseta. \\
\multicolumn{2}{l}{ susu-Ak minum (mebuat/menyuruh )telah }
\end{tabular}

'Saya meminumkan susu kepada anak.'

Verba transitif поти 'minum' berubah menjadi verba kausatif nomaseru 'membuat/ menyuruh minum' dengan penambahan sufiks atau morfem kausatif \{ saseru\}. Pada kalimat tersebut, terkandung makna 'saya telah membuat anak menjadi meminum susu dengan jalan menyuruh atau memerintahkan anak supaya meminum susu' sehingga ada makna benefaktif dan dimarkahi dengan partikel $\boldsymbol{n i}$.

Dari segi semantis Kindaichi (1976:26) membagi verba atas empat jenis, yaitu: 
1）状態動詞 Joutai doushi 'verba statif' Verba yang menunjukkan keadaan subyek dan mengabaikan konsep waktu (tense). Sebagaimana diamati pada contoh:

$$
\begin{array}{ll}
\text { - 車が } & \text { ある。 } \\
\text { Kuruma ga } & \text { aru. } \\
\text { mobil-Nom } & \text { ada. }
\end{array}
$$

'Ada meja.'

Baik verba ある aru 'ada' masuk ke dalam kelompok verba ini karena verba aru 'ada' tidak dapat diubah ke dalam bentuk infinitif verba $+\{\sim$ te iru $\}$.

2) 継続動詞 Keizoku doushi 'verba kontinuatif'

Verba jenis ini mengimplikasikan adanya perbuatan pada waktu tertentu, dan perbuatan atau peristiwa itu terus berlangsung saat ujaran. Ciri yang paling jelas pada verba ini selalu menggunakan bentuk infinitif verba $+\{\sim$ te iru $\}$.

$$
\begin{array}{cl}
\text { - 子供が } & \text { 遊んでいる。 } \\
\text { Kodomoga } & \text { asonde iru. } \\
\text { anak-anak-Nom } & \text { bermain } \\
& \text { morf(sedang) }
\end{array}
$$

'Anak-anak sedang bermain.'

Bentuk infinitif verba $+\{\sim$ te iru $\}$ pada kalimat di atas menunjukkan makna kontinuatif. Namun, makna verba itu berbeda, bergantung pada waktu pembicara dalam mengutarakan kejadian tersebut.

3) 主観動詞 Shukan doushi 'verba pungtual' Verba jenis ini menunjukkan perbuatan sesaat. Dalam bentuk infinitif, verba + $\{\sim$ te iru\} tidak memiliki makna kontinuatif melainkan menunjukkan makna hasil perubahan sebuah perbuatan tersebut. Bentuk verba ini menjadi ciri khas dalam bahasa Jepang.

$\begin{array}{cll}\text { - 彼は } & \text { もう 結婚している。 } \\ \text { Kare wa } & \text { mou kekkon shite iru. } \\ & \text { (terus sampai sekarang) } \\ \text { ini-Top } & \text { sudah menikah } \\ & \text { melakukan-morf (sedang) }\end{array}$

'Dia sudah menikah.'
4) 弟四の動詞 Dai yon no doushi 'verba khusus'

Verba jenis ini hampir mirip dengan verba keadaaan dalam bahasa Indonesia. Dalam pemakaiannya selalu dalam bentuk infinitif verba $+\sim$ te iru. Perhatikan contoh di bawah:

$$
\begin{array}{ll}
\text { - あの人は } & \text { 高い鼻を } \\
\text { Ano hito wa } & \text { takai hanao } \\
\text { itu orang-Top } & \text { tinggi hidung-Ak } \\
\text { している。 } & \\
\text { shite iru. } & \\
\text { melakukan-morf(sedang) } & \\
\text { 'Orang itu berhidung mancung.' }
\end{array}
$$

\begin{tabular}{|c|c|c|}
\hline 3a. * & $\begin{array}{l}\text { Hanako が } \\
\text { Hanako ga } \\
\text { Hanako-Nom }\end{array}$ & $\begin{array}{l}\text { Taroo を } \\
\text { Taroo o } \\
\text { Taroo-Ak }\end{array}$ \\
\hline & $\begin{array}{l}\text { 英語を } \\
\text { eigo o } \\
\text { bahasa Inggris-Ak }\end{array}$ & $\begin{array}{l}\text { 教えます。 } \\
\text { oshiemasu. } \\
\text { mengajar }\end{array}$ \\
\hline
\end{tabular}

Pada penelitian ini membahas verba oshieru 'mengajar/ajar', ageru 'memberi', kureru 'memberi' dan kau 'membeli' yang mengambil dua objek, yaitu objek langsung dan objek tak langsung.

$\begin{array}{ll}\text { 3. Hanako が } & \text { Tarooに } \\ \text { Hanako ga } & \text { Taroo } \boldsymbol{n i} \\ \text { Hanako-Nom } & \text { Taroo-Dat } \\ \text { 英語を } & \text { 教えます。 } \\ \text { eigo o } & \text { oshiemasu. } \\ \text { bahasa Inggris-Ak } & \text { mengajar }\end{array}$

'Hanako akan mengajar bahasa Inggris kepada Taroo.' (Korpus, Gakubu:2005)

3b. Hanako が 英語を

Hanakoga eigo o

Hanako-Nom bahasa Inggris-Ak

$\begin{array}{ll}\text { Taroo に } & \text { 教えます。 } \\ \text { Taroo } n \boldsymbol{i} & \text { oshiemasu. } \\ \text { Taroo-Dat } & \text { mengajar }\end{array}$

'Hanako akan mengajar kepada Taroo bahasa Inggris.' 
Pada data kalimat (3), argumen-argumen yang muncul adalah argumen Hanako ga 'Hanako (nama orang)' merupakan agen, Taroo $n i$ 'Taroo (nama orang)' adalah objek tak langsung (OTL), dan eigo o 'bahasa Inggris' merupakan objek langsung (objek). Verba pada data kalimat (3) adalah verba bentuk dasar oshieru 'mengajar', yang mengalami proses morfologis dengan kala akan datang sopan $\{\sim$ masu $\}$ menjadi oshiemasu 'akan mengajar'. Data kalimat (3a), partikel $n i$ (datif) disubstitusi dengan partikel $o$ (akusatif) yang menyatakan argumen objek. Namun, substitusi pemarkah $o$ akusatif tersebut menjadi tidak berterima secara gramatikal bahasa Jepang. Hal itu disebut sebagai double o constraint. Data kalimat (3b), dilakukan permutasi pada argumen objek. Data kalimat (3b) dengan permutasi tersebut tetap berterima dalam bahasa Jepang.

\begin{tabular}{|c|c|}
\hline $\begin{array}{l}\text { Jiroo が } \\
\text { Jiroo ga } \\
\text { Jiroo-Nom }\end{array}$ & $\begin{array}{l}\text { Masako に } \\
\text { Masako ni } \\
\text { Masako-Dat }\end{array}$ \\
\hline $\begin{array}{l}\text { 指輪を } \\
\text { yubiwa o } \\
\text { cincin-Ak }\end{array}$ & $\begin{array}{l}\text { あげた。 } \\
\text { ageta. } \\
\text { memberi-telah }\end{array}$ \\
\hline
\end{tabular}

'Jiroo memberi cincin kepada Masako.'

(Korpus,Gengo: 1996)

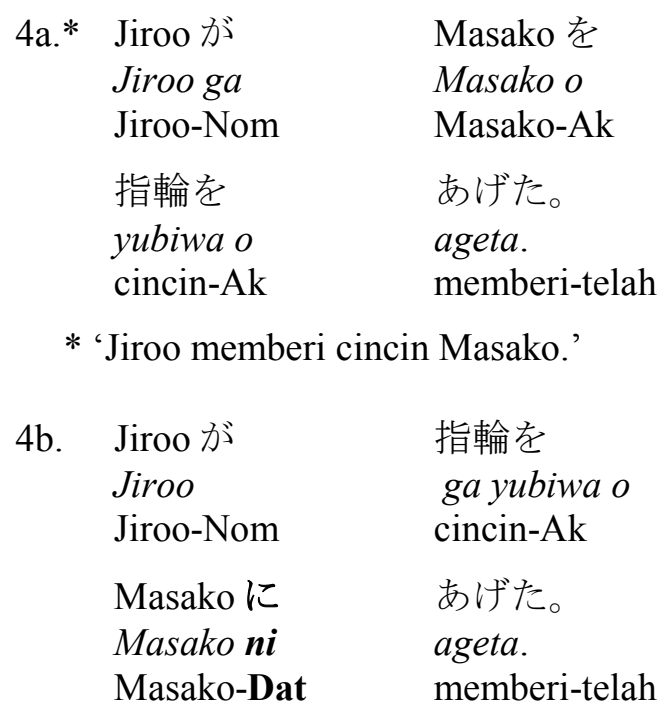

'Jiroo telah memberi kepada Masako cincin.'

Pada data kalimat (4), argumen-argumen yang muncul adalah argumen Jiroo ga 'Jiroo (nama orang)' merupakan agen, Masako ni 'kepada Masako (nama orang)' adalah objek tak langsung (OTL), dan yubiwa o 'cincin' merupakan objek langsung (objek). Verba pada data kalimat (4) adalah verba bentuk dasar ageru 'memberi', yang mengalami proses morfologis dengan kala lampau biasa $\{\sim t a\}$ menjadi ageta 'telah memberi'. Data kalimat (4a), partikel $n i$ (datif) disubstitusi dengan partikel $o$ (akusatif) yang menyatakan argumen objek. Namun, substitusi pemarkah $o$ akusatif tersebut menjadi tidak berterima secara gramatikal bahasa Jepang. Hal itu disebut sebagai double o constraint. Data kalimat (4b), dilakukan permutasi pada argumen objek. Data kalimat (4b) dengan permutasi tersebut tetap masih berterima dalam bahasa Jepang.

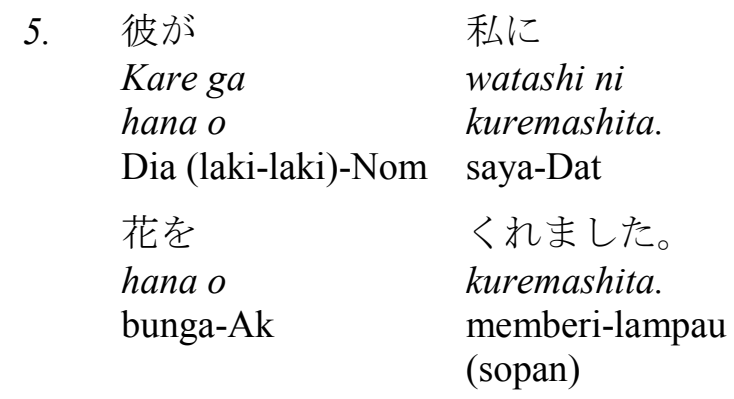

'Dia memberi bunga kepada saya.' (Korpus, Gengo: 1997)

\begin{tabular}{|c|c|c|}
\hline 5a. * & $\begin{array}{l}\text { 彼が } \\
\text { Kare ga } \\
\text { Dia (laki-laki)-Nom }\end{array}$ & $\begin{array}{l}\text { 私を } \\
\text { watashio } \\
\text { saya-Ak }\end{array}$ \\
\hline & $\begin{array}{l}\text { 花を } \\
\text { hana o } \\
\text { bunga-Ak }\end{array}$ & $\begin{array}{l}\text { くました。 } \\
\text { kuremashita. } \\
\text { memberi-lampau } \\
\text { (sopan) }\end{array}$ \\
\hline
\end{tabular}
5b. 彼が 私に
Kare ga watashi ni
Dia (laki-laki)-Nom saya-Dat
花をくれました。
hana o kuremashita.
bunga-Ak memberi-lampau
(sopan)

'Dia memberi bunga kepada saya.'

Pada data kalimat (5), argumen-argumen yang muncul adalah argumen kare ga 'dia (lakilaki)' merupakan agen, watashi $n i$ 'kepada saya' adalah objek tak langsung (OTL), dan hana o 'bunga' merupakan objek langsung (objek). 
Verba pada data kalimat (5) adalah verba bentuk dasar kureru 'memberi', yang mengalami proses morfologis dengan kala lampau sopan \{ mashita\} menjadi kuremashita. Verba kureru 'memberi' hanya dipergunakan untuk menyatakan memberi kepada kelompok persona 1, yaitu saya dan keluarga saya. Verba kureru 'memberi' dipergunakan untuk tataran yang setara. Data kalimat (5a), partikel $n i$ (datif) disubstitusi dengan partikel $o$ (akusatif) yang menyatakan argumen objek. Namun, substitusi pemarkah $o$ akusatif tersebut menjadi tidak berterima secara gramatikal bahasa Jepang. Hal itu disebut sebagai double o constraint. Data kalimat (5b), dilakukan permutasi pada argumen objek. Data kalimat (5b) dengan permutasi tersebut tetap masih berterima dalam bahasa Jepang.

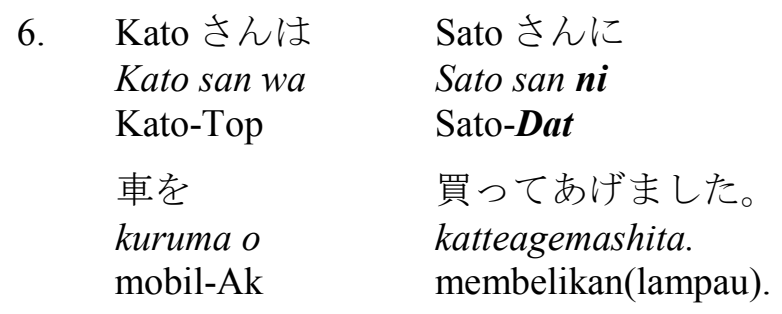

'Kato membelikan mobil untuk Sato.'

(Korpus, Gakubu:2005)

\begin{tabular}{|c|c|}
\hline $\begin{array}{cl}\text { 6a. * } & \text { Kato さんは } \\
& \text { Kato san wa } \\
& \text { Kato-Top }\end{array}$ & $\begin{array}{l}\text { Sato さんを } \\
\text { Sato san o } \\
\text { Sato-Ak }\end{array}$ \\
\hline $\begin{array}{l}\text { 車を } \\
\text { kuruma o } \\
\text { mobil-Ak }\end{array}$ & $\begin{array}{l}\text { 買ってあげました。 } \\
\text { katteagemashita. } \\
\text { membelikan(lampau). }\end{array}$ \\
\hline
\end{tabular}

* 'Kato membelikan mobil Sato.'

\begin{tabular}{|c|c|}
\hline $\begin{array}{l}\text { Kato さんは } \\
\text { Kato san wa } \\
\text { Kato-Top }\end{array}$ & $\begin{array}{l}\text { 車を } \\
\text { kuruma o } \\
\text { mobil-Ak }\end{array}$ \\
\hline $\begin{array}{l}\text { Sato さんに } \\
\text { Sato san } \boldsymbol{n i} \\
\text { Sato-Dat }\end{array}$ & $\begin{array}{l}\text { 買ってあげました。 } \\
\text { katteagemashita. } \\
\text { membelikan(lampau). }\end{array}$ \\
\hline
\end{tabular}

'Kato membelikan Sato mobil.'

Pada data kalimat (6), argumen-argumen yang muncul adalah argumen Kato san ga 'Kato (nama orang)' merupakan agen, Sato san ni 'kepada Sato' adalah objek tak langsung (OTL), dan kuruma o 'mobil' merupakan objek langsung (objek). Verba pada data kalimat (6) adalah verba bentuk dasar kau 'membeli', yang mengalami proses morfologis dengan $\{\sim t e\}$ dari verba bentuk dasar kau 'membeli' + ageru 'memberi' = katteageru + kala lampau sopan \{ mashita menjadi katteagemashita. Verba katteagemashita tersebut dalam bahasa Indonesia menjadi bermakna membelikan. Data kalimat (6a), partikel $n i$ (datif) disubstitusi dengan partikel $o$ (akusatif) yang menyatakan argumen objek. Namun, substitusi pemarkah $o$ akusatif tersebut menjadi tidak berterima secara gramatikal bahasa Jepang. Hal itu disebut sebagai double o constraint. Data kalimat (6b), dilakukan permutasi pada argumen objek. Data kalimat (6b) dengan permutasi tersebut tetap masih berterima dalam bahasa Jepang.

\section{SIMPULAN}

Bahasa Jepang merupakan bahasa yang bermarkah, dalam arti bahwa dalam setiap konstituen bahasa Jepang (BJ), terdapat pemarkah untuk menjelaskan fungsinya. Objek dalam bahasa Jepang dapat dibagi menjadi dua, yaitu objek langsung dan objek tak langsung. Berdasarkan analisis di atas, dapat dibuat simpulan sebagai berikut ini.

1) Verba yang memerlukan kehadiran objek ganda merupakan verba transitif atau verba aksi yang berupa objek tak langsung (OTL), berpemarkah ni. Pemakaian pemarkah $o$ akusatif pada struktur kalimat bahasa Jepang berobjek ganda, tidak diperbolehkan secara gramatikal bahasa Jepang, karena mempunyai fungsi yanng berbeda.

2) Verba yang dianalisis dalam penelitian ini hanyalah verba ageru 'memberi', oshieru 'mengajar/ajar', kureru 'memberi', dan kau 'membeli' saja. Verba-verba tersebut merupakan jenis keizoku doushi 'verba kontinuatif'.

Verba jenis ini mengimplikasikan adanya perbuatan pada waktu tertentu, dan perbuatan atau peristiwa itu terus berlangsung saat ujaran. Pada dasarnya, verba-verba tersebut $\mathrm{di}$ atas memerlukan kehadiran tiga argumen, yaitu agumen subjek, argumen objek tak langsung, dan argumen objek langsung. 


\section{DAFTAR PUSTAKA}

Aryani, MRD. 2017. "Datif dalam Bahasa Jepang: Kajian Sintaktis dan Semantis" (disertasi). Bandung: Universitas Padjadjaran.

Blake, Barry J.2001. Case. Cambridge: Cambrige University Press

Givon, Talmy.(2001). Syntax An Introduction. Vol I. Amsterdam: John Benjamins Publishing Company.

Katamba, Francis. 1993. Modern Linguistics: Morphology. London: The Macmillan Press

Kindaichi, Haruhiko. (1976). Nihongo. "Bahasa Jepang". Tokyo : Iwanami Shoten.
Nitta, Yoshio.(1991). Nihongo Bunpou Kenkyuu Josetsu. Toukyou-Japan: Kuroshio Shuppan.

Shibatani, Masayoshi. 2012. Grammatical Relations and Surface Cases. USA: Linguistic Society of America http://www.jstor.org/page/info/about/polic ies/terms.jsp.

Tsunoda, Tasaku.(2002). Sekai no Gengo to Nihongo: Gengo Ruikeiron kara Mita Nihongo. Tokyo: Kuroshio Shuppan.

Verhaar, JWM. 1999. Asas- Asas Linguistik Umum. Yogyakarta: Gadjah Mada University. 